\title{
Meta-analytical study of the effect of fibers in neutral detergent and acidic detergent in the diet of finishing pigs
}

\author{
Joselito Bastos da Silva Júnior ${ }^{1}$ (D) Leonardo Augusto Fonseca Pascoal ${ }^{1 *}$ (D) \\ Ines Andretta ${ }^{2}$ (D) Marcos Kipper da Silva ${ }^{2}$ (D) Luciano Hauschild ${ }^{3}$ (D) \\ Bruna Kuhn Gomes² (D) Carolina Schell Franceschina ${ }^{2}$ (D)
}

${ }^{1}$ Universidade Federal da Paraíba (UFPB), 58397-000, Areia, PB, Brasil. E-mail: leonardo@cchsa.ufpb.br. "Corresponding author.

${ }^{2}$ Faculdade de Agronomia, Universidade Federal do Rio Grande do Sul (UFRGS), Porto Alegre, RS, Brasil.

${ }^{3}$ Faculdade de Ciências Agrárias e Veterinárias, Universidade Estadual Paulista “Júlio de Mesquita Filho" (UNESP), Jaboticabal, SP, Brasil.

ABSTRACT: Performance and carcass traits of finishing pigs fed diets containing different levels of neutral detergent fiber (NDF) and acid detergent fiber $(A D F)$ were evaluated through meta-analysis. The database was constructed using information from 24 papers, 113 treatments, and 2507 animals. Correlation and variance analyze were performed. The weight gain of the pigs showed a negative correlation (P < 0.01$)$ with the dietary NDF content and with NDF consumption. The feed conversion ratio showed a positive correlation $(P<0.01)$ with the inclusion of $A D F$ in the test ingredient and with the consumption of NDF and ADF. The backfat thickness showed a negative correlation ( $P<0.05)$ with the NDF content in the diets. The analysis of variance showed that the performance of finishing pigs was not influenced (P $>0.05)$ by the inclusion of ingredients with high NDF content. Likewise, the inclusion of ingredients with high ADF content did not alter (P $>0.05)$ feed intake and feed conversion ratio. However, the use of ingredients with a high ADF content reduced $(P<0.05)$ by $4 \%$ the weight gain of the pigs. The use of ingredients with high concentrations of NDF and ADF negatively affect the weight gain and feed conversion of finishing pigs; however, the ADF-related fraction has a positive relationship with the reduction of the backfat thickness.

Key words: backfat thickness, carcass characteristics, dietary fiber, lignin, performance.

Estudo meta-analítico do efeito das fibras em detergente neutro e detergente ácido na dieta de suínos em terminação

RESUMO: O desempenho e as características de carcaça de suínos em terminação alimentados com dietas contendo diferentes níveis de fibra em detergente neutro (FDN) e fibra em detergente ácido (FDA) foram avaliados por meio de meta-análise. O banco de dados foi construido com informações de 24 artigos, 113 tratamentos e 2.507 animais. Análises de correlação e variância foram realizadas. O ganho de peso dos suínos apresentou correlação negativa $(P<0,01)$ com o teor de FDN da dieta e com o consumo de FDN. A taxa de conversão alimentar apresentou correlação positiva $(P<0,01)$ com a inclusão de FDA presente nos ingredientes testados e com o consumo de FDN e FDA. A espessura do toucinho apresentou correlação negativa $(P<0,05)$ com o teor de FDN das dietas. A análise de variância mostrou que o desempenho dos suínos em terminação não foi influenciado $(P>0,05)$ pela inclusão de ingredientes com alto teor de FDN. Da mesma forma, a inclusão de ingredientes com alto teor de FDA não alterou $(P>0,05)$ o consumo de ração e a conversão alimentar. Porém, o uso de ingredientes com alto teor de FDA reduziu $(P<0,05)$ em $4 \%$ o ganho de peso dos suínos. O uso de ingredientes com altas concentrações de FDN e FDA afetam negativamente o ganho de peso e conversão alimentar de suínos em terminação, porém fração relacionada a FDA tem relação positiva com a redução da espessura de toucinho.

Palavras-chave: caracteristicas de carcaça, desempenho, espessura de toucinho, fibra alimentar, lignina.

\section{INTRODUCTION}

Including fibrous ingredients in pig diets is a way to reduce feeding costs (ALBUQUERQUE et al., 2011). In addition, dietary fiber may have positive effects on intestinal health and also on animal welfare by improving satiety sensation. A minimum level of fiber in diets is necessary for the maintenance of normal physiological function of the digestive tract. This negative effect of dietary fiber on non-ruminant animals is dependent on the specific properties of each fiber, which will vary considerably between the ingredient used (BRITO et al., 2008; ABELILA \& STEIN, 2019).

Use of fibrous ingredients in diets for finishing pigs aims to reduce feed costs and provide less fat deposition in the carcass (WIDMER et al. 2008; WATANABE et al. 2010). Fiber fractions can be measured by several methods of analysis, but the most common for farm animals are the determinations 
of crude fiber, neutral detergent fiber and acid detergent fiber. The methods used to measure the fibrous fractions of foods are correlated to simulate enzymatic digestion, but with difficult practical application (NEPOMUCENO et al., 2016) and or have limitations such as crude fiber. The method proposed by Van Soest (1967) determines the fractions of neutral detergent fiber (Hemicellulose and cellulose) and acid detergent fiber (cellulose) insoluble fractions (PASCOAL \& WATANABE, 2014; NEPUCENO et al., 2018). With the determination of the neutral detergent fiber and acid detergent fiber values, we can calculate the insoluble hemicellulose fractions, cellulose and lignin of the ingredients (ABELILLA \& STEIN, 2019) improving its use and indication in diets for finishing pigs according to the objective of the food program.

Pigs in the finishing phase have high fat deposition and to limit this negative point, the use of fibrous ingredients in qualitative food restriction programs has been proposed, as it aims to reduce the nutritional density of the diets (FRAGA et al., 2008, WATANABE et al., 2010, SILVA et al. 2016), the choice of fiber source is still debatable, and therefore the determination of fiber values in neutral detergent and acid detergent by the methodological aspect and by representing more coherent the fiber content of the ingredients, it becomes pertinent to look for how these fractions affect the performance and carcass characteristics of finishing animals. The results of previous research on the effect of dietary fiber on finishing pigs are quite heterogeneous. This variability is probably caused by the diversity of experimental conditions in which this factor was tested. The meta-analysis is a technique with good possibilities of application in this context, since it is an analytical tool that combines results obtained in several studies making a reproducible synthesis of the data, with increased statistical power to investigate the effects of the treatments. In the case of discordant effects, the meta-analytical study also provides an overview of the situation. Thus, a meta-analytical study was developed to evaluate the performance and carcass characteristics of finishing pigs fed with diets containing different levels of fibrous ingredients.

\section{MATERIALS AND METHODS}

Indexed publications that addressed the inclusion of fibrous ingredients in diets for finishing pigs were selected. The research strategy of the papers was the consultation of different digital databases (Google Scholar, Science Direct, Scopus, Scielo, and
PubMed). Once identified, the scientific papers were critically evaluated for their relevance to the metaanalysis objectives. In this step, a set of information about each of the selected articles was analyzed, including items related to experimental design, treatments, variables studied, and data analysis.

Then, the selected studies were submitted to a checklist in order to evaluate their inclusion in the present meta-analysis. The main criteria for the selection of publications were: (a) to evaluate feeds with fibrous ingredients compared to basal formulations based on corn and soybean meal; (b) to use high-performance swine genotypes with body weight compatible with the finishing phase; and (c) to present performance responses and/or carcass characteristics. The selection of publications was independently performed by two reviewers based on the above criteria. Only studies published in indexed journals were selected, considering the acceptance for publication as a subjective criterion for their methodological quality. The results (positive or negative) of the treatment were not considered as criteria for paper selection.

The variables considered in the construction of the database were defined according to their availability in the selected papers and with the pertinence to the objectives of the study, being grouped in: experimental characteristics, nutritional profile of the diets, performance responses, and carcass characteristics. This information was obtained in the papers (material and methods, results, and tables) and included in a spreadsheet.

The inclusion of the ingredients (in the feed formulas) presented in the articles was used to calculate the nutritional composition of the diets. This procedure was adopted to guarantee the standardization of the nutritional bases among the papers. The composition of the ingredients conventionally used in pig diets was obtained from the Brazilian tables for Poultry and Swine (ROSTAGNO et al., 2005). Due to the high variety of fibrous ingredients tested in the studies that composed the database, other references were necessary to consider the participation of these ingredients in the nutritional composition of the feeds. The compositions and references used in these cases are presents in table 1 . The values obtained in the calculation of the nutritional composition were multiplied by the average daily feed intake to obtain the average daily consumption of each nutritional component, especially the fibrous components.

The methodology for the definition of the dependent and independent variables and for the codification of the data followed the propositions 
Table 1 - Bromatological composition (\%) of the fibrous ingredients used to calculate the composition of experimental diets.

\begin{tabular}{|c|c|c|c|c|c|c|c|c|}
\hline Ingredients & $\mathrm{DM}$ & $\mathrm{CP}$ & $\mathrm{L}$ & MM & NDF & $\mathrm{ADF}$ & HEM & LIG \\
\hline Alfafa $^{1}$ & 91.4 & 13.8 & 2.2 & 9.9 & 47.0 & 33.2 & 13.8 & 8.3 \\
\hline Black oat $^{2}$ & 88.1 & 9.8 & 4.8 & 2.6 & 32.8 & 14.9 & 17.9 & 2.5 \\
\hline Poultry litter ${ }^{3}$ & 16.6 & 17.0 & 0.4 & 22.5 & 63.2 & 39.2 & 24.0 & 0.0 \\
\hline Barnyardgrass ${ }^{4}$ & 11.3 & 9.4 & 3.8 & 8.4 & 71.0 & 35.0 & 36.0 & 5.3 \\
\hline Sticky coffee hull ${ }^{5}$ & 93.5 & 8.8 & 1.1 & 6.4 & 34.4 & 27.7 & 6.7 & 5.2 \\
\hline Sticky coffee hull silage ${ }^{6}$ & 67.5 & 10.0 & 1.9 & - & 29.0 & 23.9 & 5.3 & 5.6 \\
\hline Soybean hull ${ }^{7}$ & 89.4 & 12.0 & 1.3 & 4.7 & 62.0 & 45.6 & 16.4 & 3.0 \\
\hline Barley $^{8}$ & 88.9 & 10.7 & 1.3 & 2.2 & 18.7 & 5.5 & 13.3 & 0.9 \\
\hline Wheat bran 9 & 87.1 & 16.2 & 3.9 & 4.5 & 47.0 & 13.7 & 33.3 & 5.0 \\
\hline Corn germen meal ${ }^{10}$ & 91.1 & 10.2 & 1.3 & 6.4 & 29.0 & 7.5 & 21.5 & 1.9 \\
\hline Cassava residue $^{11}$ & 92.7 & 1.3 & 0.3 & 6.6 & 30.5 & 22.7 & 7.8 & - \\
\hline Tifton hay $^{12}$ & 82.4 & 15.5 & 1.2 & 7.7 & 79.2 & 34.3 & 44.9 & - \\
\hline Corn germen ${ }^{13}$ & 90.6 & 15.6 & 17.3 & 5.4 & 37.1 & 10.4 & 26.7 & 5.5 \\
\hline Distillery grains ${ }^{14}$ & 27.7 & 23.9 & 10.3 & 3.6 & 31.7 & 11.4 & 20.3 & 8.2 \\
\hline Sunflower grains ${ }^{15}$ & 92.7 & 27.5 & 3.1 & 6.2 & 43.6 & 32.9 & 10.7 & 10.0 \\
\hline Citrus pulp ${ }^{16}$ & 89.1 & 6.3 & 3.2 & 7.9 & 18.8 & 14.3 & 4.5 & 1.3 \\
\hline Dehydrated brewery residue ${ }^{17}$ & 21.8 & 21.9 & 8.0 & 6.0 & 55.2 & 24.4 & 30.7 & 4.6 \\
\hline Low tannin sorghum ${ }^{18}$ & 28.0 & 9.8 & 2.2 & 6.7 & 48.4 & 40.1 & 8.4 & 4.7 \\
\hline Mesquite pod meal ${ }^{19}$ & 87.9 & 11.9 & 3.7 & 4.7 & 20.9 & 13.5 & 7.4 & 3.8 \\
\hline
\end{tabular}

DM Dry Matter; CP Crude Protein; L Lipids; MM Mineral Matter; NDF Neutral Detergent Fiber; ADF Acid Detergent Fiber; HEM Hemicellulose; LIG Lignin.(-) Values not found in the literature.Bibliographic references indicated by: 1 Powley et al., 1981 ; ${ }^{2}$ Soares et al., 1995; ${ }^{3}$ Bellaver et al., 1984; ${ }^{4}$ Dutra Junior, et al., 1994; ${ }^{5}$ Parra et al., 2008; ${ }^{5}$ Oliveira et al., 2002; ${ }^{6}$ Carvalho et al., $2011 ; 7$ Quadros et al., 2008; 7 Gentilini et al., 2008; ${ }^{8}$ Fialho et al., 1992; ${ }^{9}$ Fialho et al., 1986; ${ }^{10}$ Moreira et al., 2002; ${ }^{11}$ Bertol et al., $1999 ;{ }^{12}$ Gomes et al., 2008; ${ }^{13}$ Widmer et al., 2008; ${ }^{14}$ Linneen et al., 2008; ${ }^{14}$ Whitney et al., 2006; ${ }^{14}$ Hilbrands et al., 2013; ${ }^{15}$ Carellos et al., 2005; ${ }^{16}$ Watanabe et al., 2010; ${ }^{17}$ Albuquerque et al., 2011; ${ }^{18}$ Moreira et al., 2014; ${ }^{19}$ Pinheiros et al., 1989.

described in the literature (LOVATTO et al., 2007; SAUVANT et al., 2008). Some codes were used as qualitative criteria of grouping, a resource to associate homogeneous groups in certain criteria and to include them in the analytical models. In this particular, the main coding used was for type of diet, being: Control feeds, formulated with corn and soybean meal; or Fibrous feed, formulated with fibrous ingredients. Other codes were used as adjustment variables in the analyzes, in order to consider the variability of the compiled studies (study effect, inter and intra effects). For the coding of the study (general), a specific sequential number was assigned to each study inserted in the database. The inter-code was formed by joining the general coding with sequential numbers, so as to assign a specific code for each treatment of the database. Intra-code, similar to that used for previous analysis, was attributed to groups with time-repeated measurements.

The meta-analysis followed three sequential analyzes: graphic (to control the quality of the database and to observe data consistency), correlation (among the various variables, to identify the related factors), and variance (to compare the treatments). The variance analyzes were performed using the General Linear Model procedure, considering the level of significance of $5 \%$. The effects of study (random effect) and treatment (fixed effect) were included in the statistical models. No weighting was used in the statistical analyzes, due to the scarcity of descriptive statistics measures in the articles used for the database. The normality of the residues was evaluated by the Ryan-Joiner test. All analyzes were performed through the Minitab 18 program (Minitab for Windows, v. 18, Pine Hall Rd, Pennsylvania, USA).

\section{RESULTS AND DISCUSSION}

The database was composed of 24 complete papers published in scientific journals. A brief description of these papers is presented in table 2 . In the set of selected publications, the studies with focus on acid detergent fiber (ADF) were more recent 
Table 2 - Description of papers used in the database.

\begin{tabular}{|c|c|c|c|c|c|c|}
\hline First author & Year of publication & Average weight, kg & Animals, $\mathrm{n}$ & Fibrous ingredient tested & \multicolumn{2}{|c|}{ Inclusion level (\%) } \\
\hline \multicolumn{5}{|c|}{ 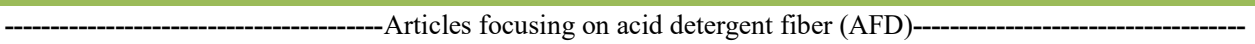 } & Min. & Max. \\
\hline Quadros $^{1}$ & 2008 & 74.2 & 40 & Soybean hull & 4 & 16 \\
\hline Bellaver $^{2}$ & 1984 & 72.0 & 200 & Poultry litter & 5 & 15 \\
\hline Bertol $^{3}$ & 1999 & 73.5 & 48 & Cassava residue & 6 & 30 \\
\hline Carellos ${ }^{4}$ & 2005 & 81.0 & 80 & Sunflower grains & 4 & 16 \\
\hline Carvalho $^{5}$ & 2011 & 76.2 & 55 & Sticky coffee hull silage & 4 & 16 \\
\hline Figueiredo $^{6}$ & 2012 & 76.6 & 40 & Cassava foliage hay & 5 & 20 \\
\hline Gentilini $^{7}$ & 2008 & 74.3 & 24 & Soybean hull & 6 & 18 \\
\hline Gomes $^{8}$ & 2010 & 65.5 & 24 & Tifton hay & 10 & 10 \\
\hline Hilbrands $^{9}$ & 2013 & 81.5 & 162 & Distillery grains & 20 & 40 \\
\hline Moreira $^{10}$ & 2014 & 77.1 & 27 & Low tannin sorghum & 25 & 50 \\
\hline Oliveira $^{11}$ & 2002 & 73.0 & 120 & Sticky coffee hull & 5 & 15 \\
\hline Parra $^{12}$ & 2008 & 73.3 & 40 & Sticky coffee hull & 2 & 20 \\
\hline Pinheiros ${ }^{13}$ & 1989 & 76.0 & 32 & Mesquite pod meal & 20 & 60 \\
\hline Powley $^{14}$ & 1981 & 74.6 & 40 & Alfafa & 20 & 60 \\
\hline Watanabe ${ }^{15}$ & 2010 & 106.7 & 36 & Citrus pulp & 10 & 30 \\
\hline \multicolumn{5}{|c|}{ 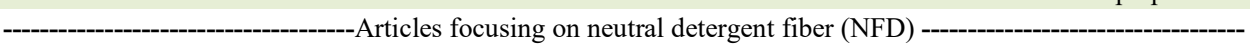 } & Min. & Max. \\
\hline Albuquerque $^{16}$ & 2011 & 75.7 & 40 & Dehydrated brewery residue & 5 & 20 \\
\hline Dutra Junior $^{17}$ & 1994 & 59.8 & 16 & Barnyardgrass & 10 & 30 \\
\hline Fialho $^{18}$ & 1986 & 77.0 & 24 & Wheat bran & 15 & 45 \\
\hline Fialho $^{19}$ & 1992 & 77.5 & 60 & Barley & 20 & 80 \\
\hline Linneen $^{20}$ & 2008 & 85.1 & 1112 & Distillery grains & 10 & 30 \\
\hline Moreira $^{21}$ & 2002 & 67.2 & 32 & Corn germen meal & 10 & 20 \\
\hline Soares $^{22}$ & 1995 & 72.5 & 20 & Black oat & 15 & 45 \\
\hline Whitney $^{23}$ & 2006 & 109.6 & 239 & Distillery grains & 10 & 30 \\
\hline Widmer $^{24}$ & 2008 & 79.0 & 36 & Dried distillers grains & 10 & 20 \\
\hline
\end{tabular}

Bibliographic references indicated by: ${ }^{1}$ Quadros et al., 2008; ${ }^{2}$ Bellaver et al., 1984; 3 Bertol et al., 1999; ${ }^{4}$ Carellos et al., 2005; ${ }^{5}$ Carvalho et al., 2011; ${ }^{6}$ Figueiredo et al., 2012; ${ }^{7}$ Gentilini et al., 2008; ${ }^{8}$ Gomes et al., 2010; ${ }^{9}$ Hilbrands et al., 2013; ${ }^{10}$ Moreira et al., 2014; ${ }^{11}$ Oliveira et al., 2002; ${ }^{12}$ Parra et al., 2008; ${ }^{13}$ Pinheiro et al., 1989; ${ }^{14}$ Powley et al., 1981; ${ }^{15}$ Watanabe et al., 2010; ${ }^{16}$ Albuquerque et al., 2011; ${ }^{17}$ Dutra Júnior et al., 1994; 18 Fialho et al., 1986; ${ }^{19}$ Fialho et al., 1992; ${ }^{20}$ Linneen et al., 2008; ${ }^{21}$ Moreira et al, 2002; Soares et al., 1995; ${ }^{23}$ Whitney et al., 2006; ${ }^{24}$ Widmer et al., 2008.

(year of publication; average: 2004, mode: 2008) than those of neutral detergent fiber (NDF) (average: 2001; mode: 2008). China (21\% of articles), Brazil (15\%) and Spain (11\%) were the countries that contributed greatly with the studies (considering the institution of the first author).

Data from 113 treatments and 2507 animals (1403 males and 1104 females) were used in the database. Considering the coding for treatment, 572 animals were submitted to the control diets and 1935 animals were submitted to treatments containing fibrous ingredients. The mean duration of the experiments was 44 days, and the initial and final weight of the pigs were $59.2 \pm 12.4 \mathrm{~kg}$ and $96.3 \pm$ $12.4 \mathrm{~kg}$, respectively.
The data on production performance and carcass characteristics obtained in studies using the fibrous ingredients focused on the NFD and AFD fractions, demonstrate the variability according to the fibrous ingredients used in the studies (Table 3). For the performance variables, it was found that for feed consumption, weight gain and feed conversion, there were differences of $39.52,38.86$ and $33.28 \%$, respectively, between the maximum and minimum values obtained in the studies. This is explained because the diets had levels of inclusion of the fibrous ingredients of which they had different concentrations of neutral detergent fiber and acid detergent fiber, which affect differently in the digestibility of the diets, according to the concentration of each fraction (OLIVEIRA et al., 2017). 
Table 3 - Calculated variables of used in studies of ingredients fibrous in finishing pigs.

\begin{tabular}{|c|c|c|c|c|c|}
\hline Variables & Average & Minimum & Maximum & MSE & $\mathrm{CV}$ \\
\hline Daily feed intake, $\mathrm{g}$ & 2460.71 & 1548.00 & 3916.83 & 30,47 & 18.41 \\
\hline Daily weight gain, g & 796.66 & 410.00 & 1055.00 & 7.04 & 13.14 \\
\hline Feed conversion ratio & 3.12 & 2.19 & 6.58 & 0.042 & 20.30 \\
\hline Hot carcass yield, $\%$ & 83.25 & 74.50 & 93.80 & 0.890 & 5.75 \\
\hline Cold carcass yield, $\%$ & 75.68 & 39.41 & 89.21 & 1.117 & 13.93 \\
\hline Backfat thickness, mm & 2.67 & 1.27 & 4.25 & 0.058 & 22.48 \\
\hline Ham weight, kg & 11.26 & 9.46 & 13.90 & 0.146 & 8.63 \\
\hline Carcass length, cm & 92.88 & 77.50 & 99.00 & 0.425 & 3.91 \\
\hline Loin area, $\mathrm{cm} 2$ & 35.03 & 21.25 & 50.10 & 0.727 & 19.25 \\
\hline
\end{tabular}

MSE Mean Standard Error; CV Coefficient of variation.

The correlation among responses and the fiber content of the feeds (calculated composition, (Table 4), the inclusion of fibrous ingredient in the feeds (Table 5), and the fiber consumption (calculated using feed composition and feed intake, table 6) were evaluated. The weight gain of the pigs showed a negative correlation with the NDF content and consumption $(P<0.01)$. The same performance variable was negatively correlated with the content $(P<0.05)$, ingredient inclusion $(P<0.01)$ and

Table 4 - Correlations of the dietary fiber content with the performance responses and carcass characteristics of finishing pigs.

\begin{tabular}{lcc}
\hline & & \\
& NDF & ADF \\
\hline Performance & & \\
\hline Daily weight gain & $-0.239^{* *}$ & $-0.269^{*}$ \\
Daily feed intake & $\mathrm{NS}$ & $\mathrm{NS}$ \\
\hline Feed conversion ratio & $\mathrm{NS}$ & $\mathrm{NS}$ \\
\hline Carcass traits & & \\
\hline Hot carcass yield & $\mathrm{NS}$ & $-0.710^{*}$ \\
\hline Cold carcass yield & $\mathrm{NS}$ & $\mathrm{NS}$ \\
\hline Backfat thickness & $-0.235^{* *}$ & $\mathrm{NS}$ \\
\hline Ham weight & $\mathrm{NS}$ & $-0.348^{* *}$ \\
\hline Carcass length & $\mathrm{NS}$ & $\mathrm{NS}$ \\
\hline Loin area & $\mathrm{NS}$ & $\mathrm{NS}$ \\
\hline
\end{tabular}

NDF Neutral Detergent Fiber; ADF Acid Detergent Fiber. Probability indicated by ${ }^{* *}(\mathrm{P}<0.01),{ }^{*}(\mathrm{P}<0.05)$ and NS (not significant). consumption $(P<0.01)$ of ADF. Feed intake did not present correlation $(P>0.05)$ with none of the studied variables. The strongest correlations (greater than $0.600 ; P<0.01)$ were observed between feed conversion and inclusion of fibrous ingredient and with the consumption of fibers in feed.

NEPOMUCENO et al. (2016) reported that higher levels of NDF in the diet directly affect the performance of pigs, since they negatively affect digestibility and thus the energy intake of animals to

Table 5 - Correlations of the inclusion of fibrous ingredient in the diets with performance responses and carcass characteristics of finishing pigs.

\begin{tabular}{llc}
\hline & NDF & ADF \\
\hline & & \\
\hline Performance & $\mathrm{NS}$ & $-0.534^{* *}$ \\
\hline Daily weight gain & $\mathrm{NS}$ & $\mathrm{NS}$ \\
\hline Daily feed intake & $\mathrm{NS}$ & $0.639^{* *}$ \\
\hline Feed conversion & & \\
\hline Carcass & $\mathrm{NS}$ & $-0.518^{*}$ \\
\hline Hot carcass yield & $\mathrm{NS}$ & $\mathrm{NS}$ \\
\hline Cold carcass yield & $\mathrm{NS}$ & $\mathrm{NS}$ \\
\hline Backfat thickness & $\mathrm{NS}$ & $-0.441^{*}$ \\
\hline Ham weight & $\mathrm{NS}$ & $\mathrm{NS}$ \\
\hline Carcass length & $\mathrm{NS}$ & $\mathrm{NS}$ \\
\hline Loin area & & \\
\hline
\end{tabular}

NDF Neutral Detergent Fiber; ADF Acid Detergent Fiber. Probability indicated by ${ }^{* *}(\mathrm{P}<0.01),{ }^{*}(\mathrm{P}<0.05)$, and NS (not significant). 
Table 6 - Correlations of fiber consumption with performance responses and carcass characteristics of finishing pigs.

\begin{tabular}{|lcc}
\hline & & \\
& NDF & ADF \\
\hline Performance & & \\
\hline Daily weight gain & $-0.585^{* *}$ & $-0.548^{* *}$ \\
\hline Daily feed intake & $\mathrm{NS}$ & $\mathrm{NS}$ \\
\hline Feed conversion ratio & $0.730^{* *}$ & $0.693^{* *}$ \\
\hline Carcass traits & & \\
\hline Hot carcass yield & $-0.426^{*}$ & $\mathrm{NS}$ \\
\hline Cold carcass yield & $\mathrm{NS}$ & $\mathrm{NS}$ \\
\hline Backfat thickness & $\mathrm{NS}$ & $\mathrm{NS}$ \\
\hline Ham weight & $\mathrm{NS}$ & $\mathrm{NS}$ \\
\hline Carcass length & $\mathrm{NS}$ & $\mathrm{NS}$ \\
\hline Loin eye area & $\mathrm{NS}$ & $\mathrm{NS}$ \\
\hline
\end{tabular}

NDF Neutral Detergent Fiber; ADF Acid Detergent Fiber. Probability indicated by ${ }^{* *}(\mathrm{P}<0.01),{ }^{*}(\mathrm{P}<0.05)$, and NS (not significant).

meet growth rates. In this sense, Fraga et al. (2008), using rice husk $(64,52 \%$ NFD) in qualitative feed restriction program for pigs observed effect on animal performance. The low digestibility intestinal, and all dietary fiber components that was observed for all diets was expected because there is limited absorption of these components in the stomach (CADOGAN AND CHOCT, 2015).

The hot carcass yield presented a negative correlation $(P<0.05)$ with the ADF content and ingredient inclusion, as also observed for the consumption of NDF. The backfat thickness showed a negative correlation $(P<0.05)$ with the NDF content in the diets. In addition, the ham weight had a negative correlation $(P<0.05)$ with the ADF content and ingredient inclusion. The cold carcass yield, carcass length, and loin area showed no correlation $(P>0.05)$ with the studied characteristics of the fibrous fractions.

The negative correlation of the dietary content of fibrous fractions with weight gain and some carcass characteristics indicates that this inclusion worsens the productive performance of finishing pigs. It was already reported that fibrous diets may reduce the productivity of younger animals, such as piglets or growing pigs (GOMES et al., 2007). The performance decrease may be due to the reduction of the digestibility of the diets when the inclusion of the fibrous ingredient exceeds the recommendation
(BLAS et al., 2006). Moreover, high fiber values in the diet of non-ruminants animals decrease the available energy values due to the low fermentative capacity of these animals.

The reduction in the daily gain of pigs receiving diets containing fibrous ingredients may be due to changes in physiological functions, as well as alterations in the action of endogenous enzymes. In pigs, fiber is digested by endogenous enzymes in the small intestine and undergoes microbiological fermentation in the cecum and large intestine, but its physiological actions (water retention and gel formation) and its nutritional effects depend on its nature, dietary intake, and age-specific characteristics of the animal (DIERICK et al., 1989). According to OLIVEIRA et al. (2002), the inclusion of $20 \%$ of coffee husks in the finishing pig diet reduced daily weight gain and worsened feed conversion. In other similar work, as the inclusion of coffee husk in these diets increased, the performance responses worsened (PARRA et al., 2008).

Results indicated a correlation of fiber inclusion and reduction on backfat thickness in the pig carcass, which can be a beneficial effect due to consumer's expectations for lean cuts (GOMES at al., 2008; WATANABE et al. 2010). Reducing the carcass fat content is one of the objectives of the qualitative feed restriction programs. The energy dilution provided by the increasing inclusions of fibrous ingredients is capable to reduce the backfat thickness (DUTRA JÚNIOR et al., 2009; MOREIRA et al. 2018).

There was a negative correlation between the ADF and the warm carcass yield. This acid detergent fiber, represented by cellulose and lignin, is not digested by pigs. In addition, cellulose presents a low degree of fermentation, contributing little to the production of short-chain fatty acids, so its inclusion in diets can compromise the animal performance and the carcass characteristics (BINDELLE et al., 2008). The increase of the acid detergent fiber in the finishing pig diets reduces the time of passage of the feed through the intestine due to the increase of the motility influenced by the physical stimulus of the fiber in the intestinal wall, which reduces the absorption of nutrients and compromises the performance.

The reduction in the digestibility of the nutrients with the increase in dietary NDF, has been verified NEPUCENO et al. (2018) on average after $11 \% \mathrm{NDF}$, is in the greater presence of cellulose and lignin in diets with higher levels of fiber is 
responsible for increasing the indigestibility, because these structures are resistant to enzymatic and microbial degradation and acid hydrolysis in the gastrointestinal tracts of pigs (PASCOAL AND WATANAVE, 2014; OLIVEIRA et al. 2017). GOMES et al. (2008) tested tifton hay, an ingredient rich in NDF and with a high amount of hemicellulose $(44.9 \%)$, which is easily digested by intestinal bacterial fermentation, in feed for finishing pigs and there was no impairment in carcass characteristics. Thus, the inclusion of some ingredients, as tifton hay, in the finishing pig diets may be an alternative to production. The bacterial fermentation promoted by the microorganisms present in the intestine degrades the hemicellulose and produces short-chain fatty acids and ATP, collaborating with the energetic requirement of finishing pigs (BINDELLE et al., 2008).

There was a negative correlation between daily weight gain and NDF and ADF intake, and a positive correlation between feed conversion ratio and NDF and ADF consumption. The lower weight gain and the worse feed conversion are related to the increase of the fibrous fractions in the diets, which impairs the digestibility of the nutrients of the diets by the pigs (GOMES et al., 2007). In addition, feeds with mostly acid detergent fiber portions require high fermentation activity, increasing energy expenditure and compromising animal performance (BINDLEY et al., 2008).

The performance of finishing pigs fed basal diets or feeds containing fibrous ingredients are presented in table 7. Carcass trait analysis was not possible due to the limited number of observations available in the database. Performance of finishing pigs was not influenced $(P>0.05)$ by inclusion of high NDF content. Likewise, the inclusion of ingredients with high ADF content did not alter $(P>0.05)$ feed intake and feed conversion ratio.

However, the use of ingredients with a high ADF content reduced $(P<0.05)$ by $4 \%$ the weight gain of the pigs, reinforcing that the increase of the fiber impairs the digestibility of the other nutrients (GOMES et al., 2007). Insoluble fractions of the cell wall, when passing through the gastrointestinal tract of the pig, do not undergo degradation and act as a physical barrier capable of limiting the activity of the endogenous digestive enzymes on the cellular content, reducing the digestion and absorption of nutrients (MONTAGNE et al. 2003). In addition, the time required to completely degrade the insoluble fibrous fractions may be longer than the time in which the intake remains in the large intestine of the swine. This aspect, as well as the smaller amount of water present in the cellulose fractions leads to less fermentation of insoluble fibers impairing the absorption of nutrients.

\section{CONCLUSION}

Based on the data from this meta-analysis, it appears that the fractions of fiber in neutral detergent and acid detergent of fibrous ingredients negatively affect the weight gain and feed conversion of finishing pigs. The reduction in the backfat thickness is more associated with the consumption of ingredients rich in fiber in acid detergent.

Table 7 - Performance of finishing pigs fed diets control or diets with inclusion of fibrous ingredients.

\begin{tabular}{|c|c|c|c|}
\hline & ------ & -------------------------- & SRE \\
\hline & Control & High fiber & \\
\hline \multicolumn{4}{|l|}{ NDF } \\
\hline Daily weight gain, $\mathrm{kg} /$ day & 0.867 & $0.855 \mathrm{NS}$ & 0.034 \\
\hline Daily feed intake, $\mathrm{kg} /$ day & 2.80 & $2.78 \mathrm{NS}$ & 0.11 \\
\hline Feed conversion ratio, $\mathrm{kg} / \mathrm{kg}$ & 3.31 & $3.23 \mathrm{NS}$ & 0.20 \\
\hline \multicolumn{4}{|l|}{$\mathrm{ADF}$} \\
\hline Daily weight gain, $\mathrm{kg} /$ day & 0.823 & $0.789^{*}$ & 0.023 \\
\hline Daily feed intake, $\mathrm{kg} /$ day & 2.77 & $2.77 \mathrm{NS}$ & 0.09 \\
\hline Feed conversion ratio, $\mathrm{kg} / \mathrm{kg}$ & 3.60 & $3.45 \mathrm{NS}$ & 0.37 \\
\hline
\end{tabular}

SRE Standard residual error; NDF Neutral Detergent Fiber; ADF Acid Detergent Fiber. Probability indicated by ${ }^{* *}(\mathrm{P}<0.01),{ }^{*}(\mathrm{P}<0.05)$, and NS (not significant). 


\section{ACKNOWLEDGEMENTS}

This work was partially funded by the Coordenação de Aperfeiçoamento de Pessoal de Nível Superior (CAPES) Brasil. Leonardo Augusto Fonseca Pascoal Conselho Nacional de Pesquisa e desenvolvimento (CNPq), Brasil - Finance code 001, for a productivity in research (PQ) grant.

\section{DECLARATION OF CONFLICT OF INTEREST}

The authors declare no conflict of interest. The funding sponsors had no role in the design of the study; in the collection, analyses, or interpretation of data; in the writing of the manuscript, and in the decision to publish the results.

\section{AUTHORS' CONTRIBUTIONS}

All authors contributed equally for the conception and writing of the manuscript. All authors critically revised the manuscript and approved of the final version.

\section{REFERENCES}

ABELILLA, J. J.; STEIN, H. H. Degradation of dietary fiber in the stomach, small intestine, and large intestine of growing pigs fed corn- or wheat-based diets without or with microbial xylanase, Journal of Animal Science, v.97, p.338-352, 2019. Avaliable from: <https://doi.org/10.1093/jas/sky403>. Accessed: Mar, 29, 2021, doi: 10.1093/jas/sky403.

ALBUQUERQUE, D. M. N. et al. Dehydrated residue of brewery for finishing swine. Arquivo Brasileiro de Medicina Veterinária e Zootecnia, Belo Horizonte, v.63, n.2, p.465472, 2011. Available from: <https://doi.org/10.1590/S010209352011000200026>. Accessed: Nov. 21, 2020. doi: 10.1590/ S0102-09352011000200026.

BINDELLE, J. et al. Nutritional and environmental consequences of dietary fibre in pig nutrition: a review. Biotechnology Agronomy Society and Environment, Belgium, v.12, p.69-80, 2008. Available from: $<$ https://popups.uliege.be/1780-4507/index. php?id=2179>. Accessed: Nov. 21, 2020.

BLAS, C.; GASA, G. G. Necesidades nutricionales para ganado porcino. Fundación Española para el Desarrollo de la Nutrición Animal. Madrid, 2006. Available from: <http://www.ciap.org.ar/ Sitio/Archivos/Normas\%20PORCINO_2013rev.pdf>. Accessed: Nov, 21, 2020.

BRITO, M. S. et al. Polysaccharides not amylaceous in the monogastric nutrition - revision, Acta Veterinária Brasilica, v.2, n.4, p.111-117, 2008. Available from: <https:/doi.org/10.21708/ avb.2008.2.4.917>. Accessed: Nov. 21, 2020. doi: 10.21708/ avb.2008.2.4.917

CADOGAN, D. J., CHOCT. M. Pattern of non-starch polysaccharide digestion along the gut of the pig: contribution to available energy. Animal Nutrition, v.1, n.3, p.160-165, 2015. Avaliable from: <https://doi.org/10.1016/j.aninu.2015.08.011>. Accessed: Mar. 31, 2021, doi: 10.1016/j.aninu.2015.08.011.
CARELLOS, D. C. et al. Evaluation of sunflower meal on growth and carcass traits of finishing pigs. Ciência e Agrotecnologia, Lavras, v.29, n.1, p.208-215, 2005. Available from: http://dx.doi. org/10.1590/S1413-70542005000100026 . Accessed: Nov, 21, 2020. doi: 10.1590/S1413-70542005000100026.

FRAGA, A. L. et al. Qualitative feed restriction for heavy pigs. Revista Brasileira de Zootecnia, Viçosa, v.37, n.5, p.869875, 2008. Available from: <https://doi.org/10.1590/S151635982008000500014>. Accessed. Feb. 12, 2021. doi: 10.1590/ S1516-35982008000500014.

GENTILINI, F. P. et al. Diets containing soybean hulls for growing and finishing swine. Revista Brasileira de Agrociência, Pelotas, v.14, n.2, p.375-382, 2008. Available from: <https://doi. org/10.18539/cast.v14i2.1924>. Accessed: Nov. 21, 2020. doi: 10.18539/CAST.V14I2.1924.

GOMES, J. D. F. et al. Effects of increasing dietary fiber on digestibility, performance and carcass characteristics: I. growing and finishing gilts. Semina: Ciências Agrárias, v.28, n.3, p.483492, 2007. Available from: <http://dx.doi.org/10.5433/16790359.2007v28n3p483>. Accessed: Nov. 21, 2020. doi: $10.5433 / 1679-0359.2007 \mathrm{v} 28 \mathrm{n} 3 \mathrm{p} 483$.

GOMES, J. D. F. et al. Performance and carcass characteristics of pigs fed with tifton hay (Cynodon Dactylon). Ciência Animal Brasileira, Goiás, v.9, n.1, p.59-67, 2008. Available from: $<$ https:// www.revistas.ufg.br/vet/article/view/3661>. Accessed: Nov. 21, 2020 .

HILBRANDS, A. M. et al. Effects of abrupt introduction and removal of high and low digestibility corn distillers dried grains with solubles from the diet on growth performance and carcass characteristics of growing-finishing pigs. Journal of Animal Science, v.91, n.1, p.248-258, 2013. Available from: <https:// doi.org/10.2527/jas.2012-5162>. Accessed: Nov. 21, 2020. doi: $10.2527 /$ jas.2012-5162.

LINNEEN, S. K. et al. Effect of dried distillers with solubles on growing and finishing pig performance in a commercial environment. Journal of Animal Science, v.86, n.7, p.1579-1587, 2008. Available from: <https://doi.org/10.2527/jas.2007-0486>. Accessed: Nov. 23, 2020. doi: 10.2527 / jas.2007-0486.

LOVATTO, P. A. et al. Meta analysis in scientific research: a methodological approach. Revista Brasileira de Zootecnia, Brasília, v.36, p.285-294, 2007. Available from: <https://doi. org/10.1590/S1516-35982007001000026>. Accessed: Nov. 23, 2020. doi: 10.1590/S1516-35982007001000026.

MONTAGNE, L. et al. A review of interactions between dietary fibre and the intestinal mucosa, and their consequences on digestive health in young non-ruminant animals. Animal Feed Science and Technology, v.108, p.95-117, 2003. Available from: https://doi. org/10.1016/S0377-8401(03)00163-9. Accessed: Nov. 23, 2020. doi: $10.1016 / \mathrm{S} 0377-8401(03) 00163-9$.

MOREIRA, I. et al. Utilization of defatted corn germ meal on growing-finishing pigs feeding - Digestibility and performance. Revista Brasileira de Zootecnia, Brasília, v.31, n.6, p.22382246, 2002. Available from: <http://dx.doi.org/10.1590/S151635982002000900012>. Accessed: Nov. 23, 2020. doi: 10.1590/ S1516-35982002000900012. 
MOREIRA, F. R. C. et al. Partial replacement of corn by sorghum in pig feeding at the nursery, growing and finishing phases. Revista Brasileira de Saúde e Produção Animal, Salvador, v.15, n.1, p.94-107, 2014. Available from: <http://dx.doi.org/10.1590/ S1519-99402014000100013>. Accessed: Nov. 23, 2020. doi: 10.1590/S1519-99402014000100013.

MOREIRA, et al. Meat properties and fatty acid profile of swine fed cashew bagasse bran in qualitative food restriction program. Revista Brasileira de Zootecnia, Viçosa, v.47, e20170034,2018. Available from: <https://doi.org/10.1590/rbz4720170034>. Accessed: Apr. 11, 2021. doi: 10.1590/rbz4720170034.

NEPOMUCENO, R. C. et al. Neutral detergent fibre in piglet diets: performance and gastrointestinal implications. Ciência e Agrotecnolgia, Lavras, v.40, n.2, p.205-216, Apr. 2016. Available from: $\quad<\mathrm{http}: / / \mathrm{dx}$.doi.org/10.1590/1413-70542016402043315>. Accessed: Mar. 11, 2021. doi: 10.1590/1413-70542016402043315.

NEPOMUCENO, R. C. et al. Neutral detergent fibre in piglet diets: digestibility, performance, and deposition of body nutrients. Anais da Academia Brasileira de Ciências, Rio de Janeiro, v.90, n.1, p.439-448, Mar. 2018.Available from: <http://dx.doi. org/10.1590/0001-3765201720150532>. Accessed: Mar. 11, 2021. doi: 10.1590/0001-3765201720150532.

OLIVEIRA, S. L. et al. Coffee hulls utilization in growing and finishing pigs feeding. Ciência e Agrotecnologia, Lavras, v.26, n.6, p.1330-1337, 2002. Available from: <http://dx.doi. org/10.1590/S1516-35982008000300008>. Accessed: Nov. 23, 2020. doi: $10.1590 / \mathrm{S} 1516-35982008000300008$.

OLIVEIRA, V. et al. Pearl millet or sorghum diets with amino acids supplementation for finishing pigs. Archives of Veterinary Science, v.12, n.1, p.58-62, 2007. Available from: http://dx.doi. org/10.5380/avs.v12i1.9230. Accessed: Nov. 23, 2020. doi: $10.5380 /$ avs.v12i1.9230

OLIVEIRA et al. Fiber sources in pigs feeding. Scientia Agraria Paranaensis., v.16, n.2, abr.jun., p.145-152, 201, 2017. Available from: http://dx.doi.org/10.18188/1983-1471/sap.v16n1p145-152. Acessed: Mar. 23 2021. doi: 10.18188/1983-1471/sap.v16n1p145-152.

PASCOAL, L.A.F.; WATANABE, P.H. Fibra dietética na nutrição de suínos. In: SAKAMURA, N.K.; SILVA, J.H.V.; COSTA,
F.G.P. et al. Nutrição de não ruminantes. Funep, Jaboticabal, 2014. p.358.

PARRA, A. R. P. et al. Coffee hulls utilization in growing and finishing pigs feeding. Revista Brasileira de Zootecnia, Brasília, v.37, n.3, p.433-442, 2008. Available from: $<$ https://doi. org/10.1590/S1516-35982008000300008>. Accessed: Nov, 23, 2020. doi: $10.1590 / \mathrm{S} 1516-35982008000300008$.

QUADROS, A. R. B. et al. Different inclusion levels of soybean hull on isoenergetic growing-finishing pig diets. Ciência Rural, Santa Maria, v.38, n.2, p.463-469, 2008. Available from: $<$ https:// doi.org/10.1590/S0103-84782008000200027>. Accessed: Nov. 23, 2020. doi: 10.1590/S0103-84782008000200027.

ROSTAGNO, H. S. et al. Tabelas brasileiras para aves e suínos: composição de alimentos e exigências nutricionais. Viçosa, MG: Universidade Federal de Viçosa, 2005. 186p.

SAUVANT, D. et al. Meta-analyses of experimental data in animal nutrition. Animal, v.2, p.1203-1214, 2008. Available from: $<$ https://doi.org/10.1017/S1751731108002280>. Accessed: Nov. 23, 2020. doi: $10.1017 / \mathrm{S} 1751731108002280$.

WATANABE, P. H. et al. Effect of inclusion of citrus pulp in the diet of finishing swine. Brazilian Archives of Biology and Technology, v.53, n.3, p.709-718, 2010. Available from: <https:// doi.org/10.1590/S1516-89132010000300028>. Accessed: Nov. 23, 2020. doi: 10.1590/S1516-89132010000300028.

WIDMER, M. R. et al. Effect of feeding distillers dried grains with solubles, high-protein distillers dried grains, and corn germ to growing-finishing pigs on pig performance, carcass quality, and the palatability of pork. Journal of Animal Science, v.86, n.8, p.18191831, 2008. Available from: <https://doi.org/10.2527/jas.20070594>. Accessed: Nov. 23, 2020. doi: 10.2527/jas.2007-0594.

WHITNEY, M. H. et al. Growth performance and carcass characteristics of grower-finisher pigs fed high-quality corn distillers dried grain with solubles originating from a modern Midwestern ethanol plant. Journal of Animal Science, v.84, n.12, p.3356-3363, 2006. Available from: <https://doi. org/10.2527/jas.2006-099>. Accessed: Nov.23, 2020. doi: 10.2527/jas.2006-099. 